\title{
Lessons from Velas : Assessment of Eco-tourism as a Model for Conservation in Konkan
}

\author{
Gurudas Nulkar \\ (The author is a professor at Symbiosis Centre for Management with research interests in \\ sustainability and industrial ecology. He has published several papers in international journals and \\ also contributed chapters in books on Corporate Sustainability. \\ He is a trustee of the Ecological Society, Pune.)
}

\begin{abstract}
The potential of ecotourism in the economic and social development and its potential to conserve and nurture natural resources of the region, have been validated in many programs in the world. While the government of India has lately been using this term profusely in its Incredible India campaigns, internal acceptance by the state tourism boards towards it seems to be weak. This paper studies the Velas model of ecotourism and compares it with that in Murud. Both the places being on the Konkan coast in Maharashtra, offer a similar situation for study. Using observation and interviews, the two villages were studied and compared. The paper analyses the reasons of success at Velas and offers recommendations for Murud.

Keywords : ecotourism, konkan, conservation, sustainability, Indian coastal ecosystems
\end{abstract}

\section{Introduction}

Maharashtra is blessed with a coastline of about 700 $\mathrm{km}$. Sandwiched between the Arabian Sea on the East and the Sahyadri mountain range on the West, Konkan, as it is called, is a strip averaging $70 \mathrm{~km}$ in width. This region produces rice, coconuts, cashew nuts, and betel nuts and the sea provides a variety of fish. However, it is best known for the Alphanso mangoes which grow here. Konkan has rich deposits of bauxite and iron ore and the ports facilitate its transport to other parts of the world. Over the last decade, Konkan has grown as a tourist attraction and has witnessed uncontrolled development. Pristine beaches now offer 'second homes', agricultural fields have given way to 'farm house plots' and forested hills are being cleared for sea view bungalows. The economic prosperity of Mumbai and Pune has fuelled an increasing demand for such properties. The commissioning of the Konkan railway in 1993 further opened up trade and tourism leading to rapid changes in land use. The railway line construction demanded tunnels, ghats and viaducts which were cut through forests and across rivers in this difficult and fragile region. In the entire length of the Konkan railway, 59 stations, 179 major bridges and 1,819 minor bridges have changed the landscape dramatically (Garg,
Naswa, \& Shukla, 2013). Opening new sea ports has made way for mining, which require removal of forest cover, building roads and increased transport activities, all of which has had serious effects on the environment (Gadgil, 2010).

Revenues from tourism continue to grow and form a significant portion of incomes of the Konkan residents. Even as its environmental impacts become increasingly noticeable, little is being done at policy level to reduce the burden. The objective of this paper is to compare the impacts of standard tourism practices with those of the eco-tourism model followed in Velas village. For this purpose, two popular tourist destinations in Konkan were studied over a year. Murud, in Ratnagiri district and Velas in Raigad district were chosen for this study. Murud's popularity is on account of its beautiful beach, serene village atmosphere and proximity to Pune, while Velas's fame is due to the prolific visitors - the Olive Ridley turtles - who breed here.

\section{Methodology}

For an understanding of the land, its culture and the biodiversity in the early 1990s, a review of literature was undertaken. A book on Murud published in Marathi Murud - Aithikasik ani Sanskritik 
(Ganu, 1958) documents the region, its people, their economic activities and social life during 1950s. This gave a snapshot of Murud and its people. Along with this, another publication proved invaluable. This was the path-breaking research conducted by Prakash Gole and his team in 1997, of the Konkan region. Sponsored by the World Wild Fund for Nature, India, the report carries detailed documentation on flora and fauna, identifies eco-sensitive areas and hot spots and studies the status of mangroves in Konkan. Gole proposes guidelines for conservation and management of biodiversity and for land use in this sensitive region. This report was later printed as a book (1998) and gives a colloquial interpretation of the survey. Extant literature on eco-tourism in other countries helped develop the primary research.

After the literature review and compiling the secondary data, two teams carried out detailed surveys in Murud and Velas for collection of primary data. The teams met resort owners, shopkeepers, school children, college youth and the village Sarpanch. Several resorts and home-stays were visited by the team. Tourist feedback registers were studied. Influential persons in each village were interviewed as well. Interviews with key village persons have been video recorded. Some interviews are voice recorded and the sampled resorts and villages have been extensively photographed.

\section{About Konkan}

\section{The land}

To the east of Konkan, the Western Ghats rise up to about 1200 meters and create a natural barrier to give it the highest rainfall in Maharashtra. The eastern face of Sahyadris, as they are known in Maharashtra, gives birth to some important rivers. The shorter westflowing rivers drain into the Arabian Sea and bring rich biomass and soil from the Sahyadris. Their estuaries are highly productive ecosystems and a source of livelihood for many communities. Tracts of dense mangrove forests line many of the estuaries. A variety of coastal ecosystems, like salt marshes, mudflats, mangroves, wetlands, estuaries and bays are all seen in Konkan. They create habitats for a large variety of flora and fauna. Over centuries, local population has learned to use and manage the resources to their benefit due to which the narrow Konkan strip has been inhabited for thousands of years.

\section{The People}

The physical characteristics of the Konkan region have played a vital role in shaping the biodiversity of the land and consequently the livelihoods of the communities living there. Traders from afar have reached its shores, settled and mixed with local populations and this has shaped the cultural mélange evident today. Fishermen and sailing communities like the Kolis, Gabits and Bhois live on the coasts and have an intimate knowledge of the sea as they depend on it for their livelihood. The Agris were traditionally salt makers and tillers and today, they grow mangoes and cashew nuts. Some of them also own restaurants and resorts. The Kunbis are mainly agrarian and one of the most hard-working communities here. Their women work in the field and men are labourers. Very few own land and most Kunbis till on land owned by either Brahmins or other castes. The Bhandaris produce local alcoholic drinks like tadi and madi which is sold in the Mumbai and Pune markets. Of late, Bhandaris own hotels while others are engaged in trading with commercial centers like Mumbai. Among the Brahmins, the Chitapavans probably came here during the Peshwa supremacy. Most own land and are among the more educated in the region. The temple pujaris are Brahmins who also practice religious services which are in great demand here. The Muslims are traced back to the Arabs who landed on the coast line. At that time they built boats while today, they are mainly engaged in selling meat, bakery products, fishing supplies and as agents for land broking. The other communities include the Marathas, Nahvis, Sonars and Christians. Between them they speak a variety of dialects of Marathi, Konkani and Hindi and lend the rich cultural diversity to Konkan. The diversity in religions and castes and their preferred economic practices, has survived for over a hundred years. With the onslaught of tourists and the promise of increased incomes which they hold, the once diverse and sustainable economic practices are making way to meet the tourist demands. Due to this, many communities have been switching from their traditional sources of income to the lucrative tourism business.

\section{The Biodiversity}

The intertidal zone, the area between the highest high tide and lowest low tide, supports various forms of life. The width of the intertidal zone varies from a few meters to over $1 \mathrm{~km}$. Bays and creeks are part of the intertidal zone. The dry sand beaches are mostly 
covered with shrubs like Kevda (Pandamus utilis) and creepers like Ipomea biloba, while the sand provides shelter to various crabs like the ghost crabs, hermit crabs and fiddler crabs. Rocky beaches, on the other hand support various algae like the blue-green algae, green algae, sea lettuce or the ulva, and brown algae like Sargassum. Rocky beds trap sea water which creates habitats for sea urchins, sea cucumbers, and sea anemones.

Areas away from the coast are under cultivation. Government owned areas around streams, rivers and hills are wooded with a native tree cover. Many of these have medicinal and food value and are culturally embedded in the lives of different communities. However, few such areas are protected and are threatened by increasing economic activities. Roads, bridges, tunnels, industry, and expanding towns need space and the flora has to make way for it. Konkan has its share of devrais (literally sacred groves) or forest patches protected by social fencing - deeply rooted traditions which disallow cutting, gathering or removing anything from the devrais. This has helped preserve centuries-old forest patches which today serve as gene-banks. Most devrais are now relegated to a few acres and are shrinking rapidly (Figure 1). Additionally private forests are common in the Sahyadri-Konkan corridor as evident in the survey of WRCS (Kulkarni \& Mehta, 2013). These are interspersed with reserved forest, agricultural land and habitations.

The mangrove forests could be the densest forests remaining in the Konkan region (Shindikar, 2009). Few species of flora have adapted to be salt-tolerant and these dominate the estuaries where tidal currents

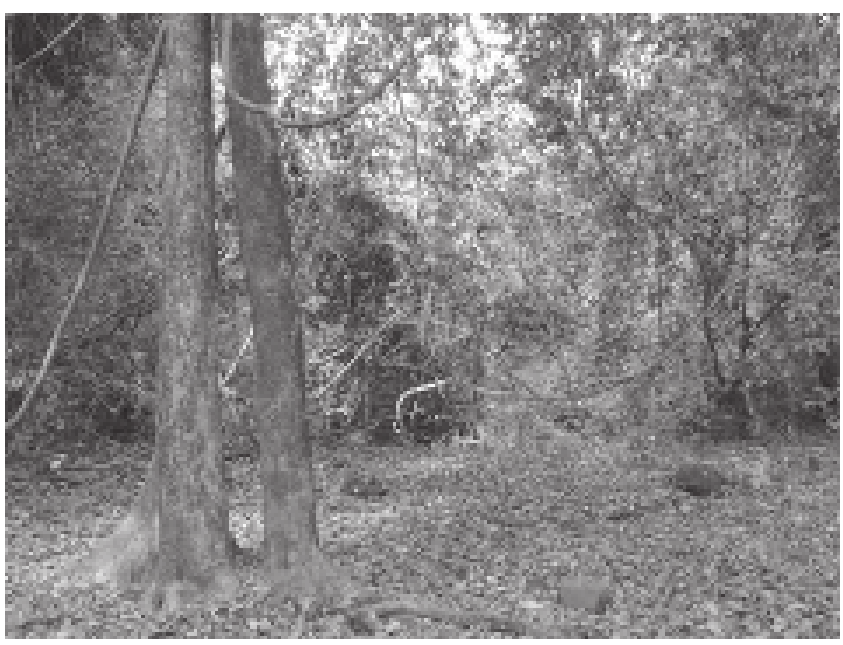

Figure 1: Kudavale Devrai near Dapoli bring in marine water which mixes with fresh water. These are highly productive ecosystems and provide home and food to an enormous number of species.

\section{Tourism in Konkan}

The magnificence of the ocean, the diversity in landscape and the cultural concoction in Konkan have always attracted tourists. The numerous places of worship too draw visitors here. Consequently, tourism has, over the last few years, turned into a major source of income for residents. Coastal towns like Vengurla, Tarkarli, Ratnagiri, Ganpatipule, Guhaghar, Murud, Velas, Murud-Jangira, Alibag, Kihim are some of the popular destinations. The ones further inland - Sawantwadi, Amboli, Marleshwar, Pawankhind, Chiplun, Lote-Parshuram, Rajapur, Lanja, Dapoli, Pen and others too have witnessed increased tourism. Tourists create a demand for local agro- horticultural produce, homemade food products and industrially processed fruit products further contributing to the local economy. The economic potential has been a strong driver for the Maharashtra state government to allot INR 500 million budget towards improvement of rural tourism in Konkan (Pawar, A, 2013). The increasing tourist activities are greeted with haphazard. Villagers' homes are converted into tourist resorts. Once deserted beaches thrive with food stalls, parasailing and dolphin boating. Weekends are particularly busy as Mumbai and Pune residents flock to the beaches. In villages which rarely saw cars, traffic jams and parking problems are now common. Tourism has also triggered roads and construction activity impacting the land use.

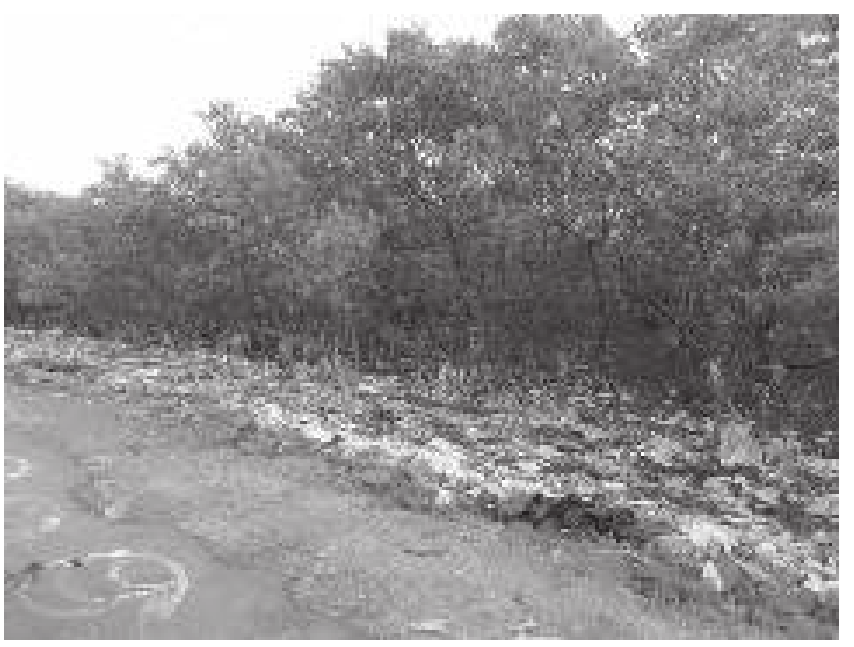

Plastic garbage stuck in mangrove roots 


\section{Tourism and Eco-tourism: the differences}

Travel undertaken for the purpose of recreation or leisure is generally termed as tourism. Such tourists place a demand for services and products which may not be easily available or not usually consumed at the place of residence. On the other hand, eco-tourism is ecologically sustainable tourism with a primary focus on experiencing local, natural things for appreciation of history, geography or culture of the region. Weaver (2001) defines eco-tourism on three counts (a) natural and cultural attractions (b) Educational and learning experiences (c) Environmental, economic and sociocultural sustainability. Eco-tourism requires understanding by and efforts of the buyers and sellers. In several countries, eco-tourism has been promoted by the government through awareness and education campaigns ${ }^{1}$. One of the debated points in eco-tourism is what scale is appropriate for this sector. Being an alternative to mass tourism, this is necessarily a much lower scale.

\section{Murud - the journey from a sleepy village to a tourist attraction}

Murud, in the 1990s was a typical coastal village with a population of a few thousand. As with most other coastal towns in Konkan, Murud has one main road running parallel to the coast. At the centre is the Durgadevi temple - the village deity. On both sides of this temple are the wadis or houses belonging to Brahmin families. The houses range from about half an acre to even a few acres. Each house has a small farm, plantations of coconuts, betelnuts and mangoes and an open well for fresh water. The principal economic activities of Murud were agriculture, horticulture and harvesting sea produce (Ganu, 1958). Graph 1 shows a comparison of economic activities in 1995 with that of 2012. The horizontal axis is an estimation of the revenue generated from the occupation. Three new economic activities are seen in 2012 - tourist resorts, tourist services and beach recreation. Mango farming has grown by $75 \%$ while restaurants and shops have grown by nearly $50 \%$.

In 1995, and more so earlier, the diversity in occupations placed a more balanced demand on available resources since the activities served needs based on the economic conditions of the locals. In the graph of 2012, tourism related occupations increased significantly leading to a skew in the demand on resources. The more affluent tourists place demands unusual to the local markets but which yield higher incomes. As increasing number of tourists flock to Murud, tourism is now a primary source of income for many. On the village main road, over 30 resorts

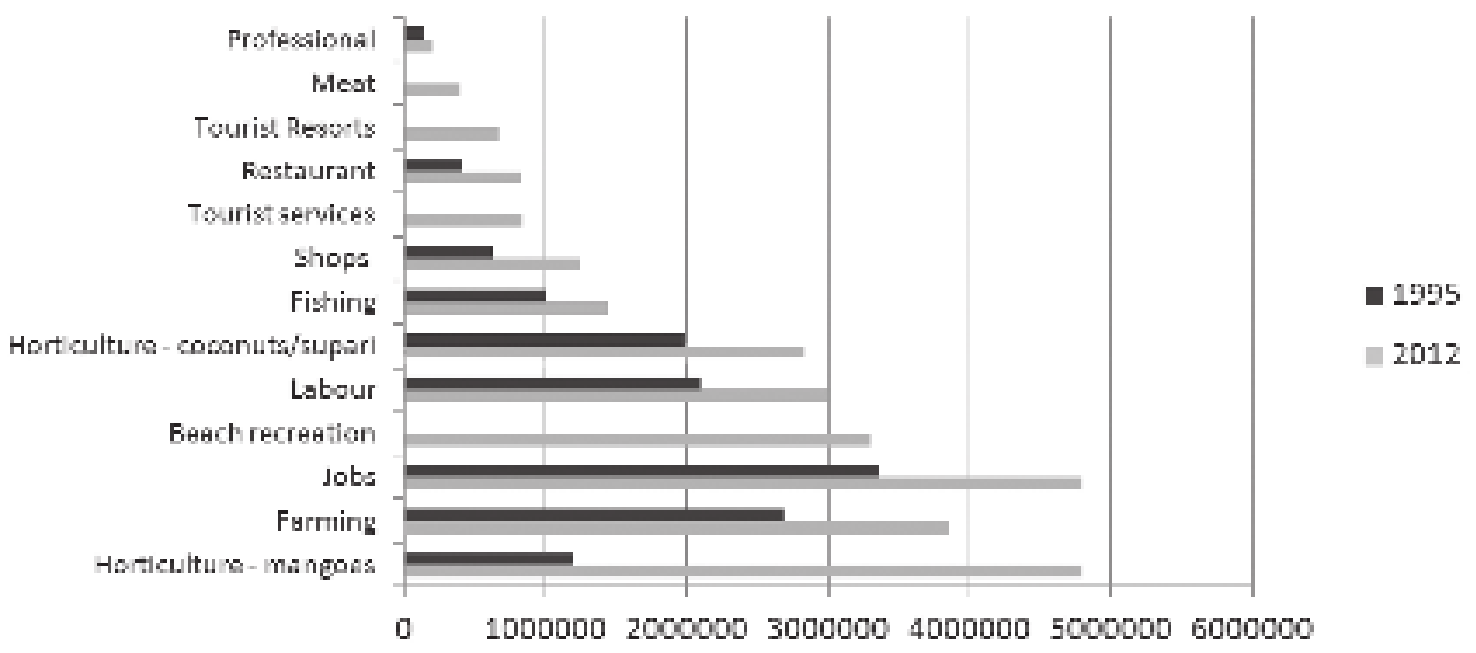

Graph 1: Economic activities in Murud over last 17 years

Data Source: Calculated with assumptions and approximations from data collected in the study.

1. http://www.ug.undp.org/content/uganda/en/home/ourwork/environmentandenergy/successstories/promoting-ecotourism-to-fight-environmental-degradation/

$h t t p: / / w w w . b m b . g o v . p h / i n d e x . p h p ? o p t i o n=c o m \_c o n t e n t \mathcal{E} v i e w=\operatorname{article} \mathcal{E} i d=255$ 
have come up and are a favorite haunt of visitors from Pune, Mumbai and even Nasik.

\section{Economics of "Resort tourism" in Murud}

The tourist season at Murud peaks between October/November (Diwali) and January. Besides the months of summer and heavy rain, most weekends too draw tourists to Murud. This offers a 150-day window for the resort owners to conduct their business. Rooms are priced between Rs. 900 to Rs. 1500 and the occupancy is nearly $50 \%$ in the 150 day season which translates to potential revenue of Rs. 75000 per room. A resort with 4 rooms would thus be capable of earning Rs. 300,000 per annum. This income exceeds the proceeds from sale of coconuts and betel nut from a 2 acre wadi and makes a compelling business proposition for the family. This is possible by making an investment in constructing rooms and purchasing requisite equipment. The operating costs in this business are low since there are no employees and cost of groceries is incrementally higher than what the resort-owner family consumes. Thus with a relatively small investment, the resort business offers assured incomes with a reasonable profitability. Consequently, Murud now has over 30 family-owned resorts with 2 to 8 rooms each. Some are registered with the MTDC and listed on their website. An affiliation with the MTDC improves visibility and helps get business. Additionally, there are 5 large resorts having 10 to 25 rooms each. This provides a wide choice for tourists with about 100 rooms at family-run resorts and about 75 rooms at large resorts, making Murud a highly competitive tourist attraction. The competition forces investments to gain a business advantage and this is evident in Murud. Table 1 lists the amenities offered in the smaller resorts and the large resorts.

Table 1 : Murud - amenities in resorts

\section{Amenities}

1 Television

2 Air conditioner

3 Fans

4 Tubes and decorative lights on campus

5 Western style toilets (WC) Occurrence

All resort rooms have a TV

At least $10 \%$ of total rooms have ACs

All resort rooms have them. Without fans, it is very uncomfortable in summer All resorts

The larger resorts mostly have them and about $25 \%$ of all rooms
6 Refrigerators

7 Chest freezers for cold drinks

The large resorts have separate kitchens and serve liquor and non-vegetarian food. They employ migrant labour from Odisha and Bihar, who are preferred over the locals, due to their willingness to work for longer hours. These migrants are culturally distant from the locals and have no connection with the land. This takes away the potential of the larger resorts to generate local employment. The large resorts sell and promote bottled water and cold drinks which have high retailer margins. Packaged snack food is widely available for the same reason. The large resorts generate more garbage per tourist, as confirmed in the interviews with locals and the group encourages voluntary beach cleaning. The family-run resorts have no dedicated employees and offer either homemade food or do not offer meals.

The tourism is supported by several services rendered by families not in the resort business. These include boating, dolphin trips, car hire, local sightseeing, parasailing, beach buggy rides and others. The Kunbhis, Bhandaris and Muslims are involved in providing these services, which require even lower investments and no special skills. This income supplements the primary source for their families. With the influx of tourists, their demand for purchasing land has increased spawing another business - land broking. Many young males have taken up dealing in land as a full time occupation. With growing land prices, this is a lucrative business. Often, tourists are voracious shoppers and this has spawned several shops. The shops stock what is demanded by tourists - bottled water, snack food, beer and wine, cosmetics, Chinese toys and even diapers. These products have higher retail margins, unlike what is demanded by locals - milk, groceries and staples.

\section{Environmental impacts of Resort tourism in Murud}

Even as the economy improved, most locals agree that the rapid growth in tourism has not been beneficial to the village. In our survey, only 2 persons did not feel that there was any significant environmental impact due to tourism. The others were aware of environmental impacts. The findings are discussed in more detail below.

a. Changes in land use - The wadis have a dense population of trees and building resort rooms requires their removal. The trees felled are usually Betelnut 
since sale of betelnuts is not highly profitable and trees like Suru (Casurina equistifolia), Ein (Terminalia elliptica), Sag (Techtona grandis) since their wood fetches good price. To get an unobstructed sea view from resorts, some sand dunes are leveled and protective strand vegetation of Kewda (Pandanus utilis) removed. This has altered the water drainage in the area. Those living next to the beach said that from last few years the sandy beach line fluctuates dramatically. Outsiders are buying agricultural land and converting it into bungalows. Ornamental trees and manicured lawns adorn areas which were once under cultivation. Large portions of fallow rocky outcrops with low soil cover are converted into cashew nut plantations by drilling in the rock and filling soil brought from another area. Increased demand for the local Chira (soft red lateritic rock used in place of bricks) has fuelled large scale quarrying on these outcrops. Highly adapted endemic vegetation of the rocky outcrop ecosystems are destroyed in the bargain (Watve, 2013).

b. Loss of biodiversity in Murud - This is most visible on the Murud beach. Prakash Gole in his report (1997) had ranked Murud beach the topmost in terms of biodiversity. His report documents Star fish, White bellied sea eagles, dune vegetation, sea cucumbers and sea urchins in 1998. During our observations, starfish, sea cucumbers and sea urchins were not recorded. Marine algae like Ulva has become rare and dune vegetation and protective cover are reduced to almost nil. These are replaced by ornamental palms and Casuarinas. The present condition of this once diverse beach is brought about by excessive tourist activities like beach buggies, parasailing and boating. Food stalls and their garbage also contribute to it. As the diversity dwindled, sea eagles are rare visitors and prefer the richer beaches of Ladghar and Kolthare.

c. Increased mango farming - As tourists sample the coastal life, many wish to own a piece of Murud. Over the last 10 years, several wadis and small land parcels surrounding Murud have been bought by residents of Mumbai and Pune. For them, the land price is ridiculously inexpensive. Several of such owners have converted agricultural land into mango farms. Agriculture, based on monsoons is being replaced with mango plantations requiring water throughout the year.

d. Depletion of fresh water in wells of Murud Resorts with bath tubs, showers and western toilets have high water consumption. It is common for visitors to have their cars washed in the resorts. Tourists from Mumbai and Pune are used to high per capita water consumption. These resorts impose a huge additional demand of fresh water on the local wells. In our survey, atleast 3 individuals have purchased small transport vehicles fitted with Plastic water tanks. They buy water from wells in Murud and sell it to the large resorts. Prior to the tourist boom, fresh water wells of Murud lasted well into May and almost upto rainfall. However, in our observations, most wells dried up by February.

e. Increased demand for energy- Resorts are energy guzzlers. Competition among them leads to enticing customers with luxuries like airconditioners, refrigerators and chest freezers for cold drinks. Bright lights decorate the resorts and pathways to the sea are well lit. This imposes high demand on energy. Uninterrupted power supply is brought about by generators and battery backed power supplies. High energy demands at resorts are paid for by the entire village going without power more often, since the supply network was not designed for the increased loads.

f. Garbage and sewage contamination - City tourists' capacity to generate garbage is multifold compared to local Murud citizens simply due to their high consumption habits. Snack foods, water bottles, cosmetics and disposable cutlery all are converted into garbage. Murud has had no village level waste management till now. Prior to the tourist influx, products which generate waste were hardly bought by locals and hence scarcely available in local shops. Villagers re-use most packaging in some way or the other and very little finds its way into landfills. However, the increased consumption capacity of the tourists has led to a monstrous challenge of waste for the locals. They have never separated garbage and have no idea of its potential to harm the environment. Stacks of garbage are dumped at the outskirts of Murud and burnt. Increased sewage generation has led to contamination with drinking water supplies. Our photographs documented the trash on the beach.

g. Demand for land by non-locals - On face value, this is perhaps a factor which has no role in environmental degradation. However, our study of Murud and surrounding region over the last 3 years has shown that increasing number of Mumbai and Pune residents are buying land here. They have no cultural or economic connection with the biodiversity. Most may not think twice before pulling down an old growth tree to construct a beach shack or obliterating a natural woodland to plant economically lucrative mango trees.

Undoubtedly, the economic fortune of Murud 
residents has improved, but the costs are borne by its environment. As Murud's economic activities converge to meet tourist demands, overuse of local resources is apparent. Environmental impacts are hardly affecting the village life today, however, over time they will manifest itself in the economy. With every new season, the scale of tourism increases. As expounded by Jared Diamond (2000) an economy which grows by ignoring the long run impacts on the environment will eventually lead to a collapse. In the age of technology, it is not the civilizations that would collapse but environmental degradation would impose high costs of living there. Polluted sources of water, poor soil and shrinking forest resources have already increased the costs in Murud as confirmed by respondents. Moreover, several industrial inputs, hardly a feature of yesteryears, are required to improve living conditions.

\section{The Eco-tourism of Velas}

In contrast, Velas, a much smaller village than Murud, about 50 kilometers north of Murud, has undertaken eco-tourism. This village shot to fame when the nests of Olive Ridley turtles (Lepidochelys olivacea) were conserved and their importance highlighted to the locals by an NGO, Sahyadri Nisarg Mitra (Katdare \& Mone, 2003). This group set up a conservation program for the dwindling number of turtles. Till 2011, over 680 nests had been protected by them (Katdare, 2012). From this turtle conservation program was born the Turtle Festival with the intention of increasing awareness of this species and linking conservancy with livelihood for the Velas residents who protect them. The Turtle Festival started in 2007 and continues every year till today, during the nesting season. The spectacular sight of hatchlings emerging from nests and crawling towards the sea draws tourists to this festival. The Velas residents offer home-stay arrangement for tourists.

\section{Velas : Economy and people}

This village is similar to Murud in many respects. The composition of the people, their religion and castes as well as their economic activities is comparable. This coastal village lies near the estuary of the Savitri River. A stream between the beach and the village offers a natural protection to the beach from the village. Cultivation and pastoral practices have been the dominant economic activities, since there are no industries - cottage or small around Velas. Mangoes, coconuts, cashew nuts and betel nuts comprise the horticultural produce while rice and

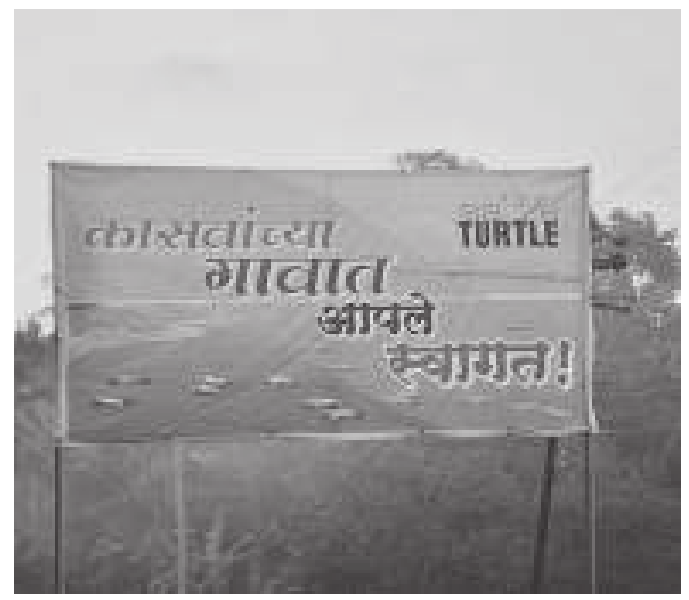

other seasonal grains are grown in fields. Whereas Murud has its own weekly market, Velas residents have to travel about $18 \mathrm{~km}$ to Mhapral, for the weekly market. Table 2 shows the 1962 demographic comparison of Murud and Velas.

$\begin{array}{lll}\begin{array}{l}\text { Aprox. Area } \\ \text { in sq.km }\end{array} & \begin{array}{l}\text { Aprox. } \\ \text { Population }\end{array} & \begin{array}{l}\text { No. of } \\ \text { households }\end{array} \\ 4.9 & 1835 & 383 \\ 8.3 & 3064 & 578\end{array}$

Table 2 : Comparison of Demographic data of 1962

Data Source: Gazetteer of the Ratnagiri District, 1962. Government of Maharashtra.

Although reliable data is not available, by 2014, the population and size of Murud has surpassed that of Velas. This was confirmed by residents. There are fundamental differences between the resort-tourism of Murud and the Home-Stay tourism of Velas. These are discussed below.

\section{a. Resort tourism in Murud-versus-Home-stays in Velas}

In Murud, the residents have built rooms for tourists away from their own homes. The rooms are built in the wadi as described earlier. In Velas, the model is home-stay. Tourists stay with the family, dine together and are treated as guests than tourists. This helps develop empathy and deeper understanding towards the locals themselves and also the turtles and the conservation program as practiced by the locals. Tourists get to live a real Konkani village life. 


\section{b. Recreation as the basis of tourism in Murud - versus- Conservation as the basis in Velas.}

Murud's economy has moved towards a tourist based one, where tourists are encouraged to take up recreation and enjoyment that has little connection with the local natural environment. New shops, hotels, restaurants and services are designed to get a share of the tourists' wallet. This ignores key traditions, cultural practices and social fences, effectively opening the village to a city based culture. Velas, on the other hand builds tourists' interests around their family and village traditions. In these times of branded international resorts and undifferentiated luxury services, tourists experience Konkani village life. Those who experience this kind of tourism, spread the word to like minded people. This, the author believes, is the cornerstone of Velas tourism and the key reason why tourists here tend to be less interested in parasailing and sipping beer at sunsets. This survey leads the author to propose that Velas tourists spend much less but contribute much more to the conservation program and improving village and its residents.

To the author, the Velas village exhibited a deep conviction to common goals which required putting individual interests behind village interests. In his classic essay, Hardin (1968) warns that divergent individual goals based on individual aspirations will inevitably lead to ruins of village commons. This is evident in Murud and documented in the earlier section. On the other hand, collective decisions in the larger interests of the village in Velas led to the choice of ecotourism over usual tourism. This is in spite of the evidence that such tourism has a high potential for profits. Some of the key decisions that set apart the Velas tourism model are discussed below in detail.

a. Decision in favour of Home-stays over resorts the author believes this to be very important basis for ecologically sensitive tourism. Even as constructing resort rooms like Murud has a higher income potential, this was not chosen to ensure the protection of the very reason why tourist come - the turtles. The home stays limit the number of tourists which is crucial in a conservation program. Moreover, the sensitivity of tourists towards conservation and environment can be improved through dialogues with the family.

b. Decision of not allowing construction on the beach - This too is a very mature agreement between the villagers. The highly sensitive turtles would in all probability stop nesting on a beach with tourist activity. This has been recorded in Murud, where the last turtle nest was seen sometime in 1994 (year unconfirmed). This decision too limits the revenue potential of Velas, for beach residence is valued more by tourists than one in the village. However, villagers have prioritized long-term conservation leading to lasting economic value over short-term financial gain.

c. Parity pricing in the home-stay business - All home-stays charge the same amount Rs 425 per person per night (as of September 2014). This reduces the competitive urge to offer 'more' to attract more business. This is another commendable agreement and one that is hardly seen in modern competitive economies, particularly tourist destinations. Through the various discussions with citizen of Velas, the author feels that this decision was driven by the awareness and education being spread by the Sahyadri Nisarg Mitra through their conservation efforts.

d. Generating funds through tourism for conservation efforts - The residents believe (especially the youth mentioned this in the interviews) that conservation can be economically sustainable by promoting managed tourism. This thinking has been brought about by the efforts of the NGO. Therefore, each home-stay owner voluntarily contributes $10 \%$ of the revenue towards the Kasav Mitra Mandal towards funding for the ongoing conservation efforts.

As expected, this sort of concurrence and aligned vision requires a strong leadership. Vishwas Katdare (known as Bhau) has played this role since the first nest conservation in 2003. Along with the Sahyadri Nisarg Mitra members, he helped the residents manage the sustainable eco-tourism program while increasing awareness and sensitivity of the villagers themselves. One resident, Mohan Upadhaye, has left his job in Mumbai and returned to Velas to manage this eco-tourism and conservancy program. Being one of the locals, he has quickly gained village approval and is an informal leader in the village conservation efforts.

\section{Economics and Management of Velas Eco- tourism}

The turtle breeding season starts in January and extends to April. In the 2014 season about 3000 visitors visited here and the 30 home-stays shared this business. Each of them made an average income of about Rs. 3000 per week. Products made by the self help groups and families themselves worth Rs. 50,000 
were sold in the season. With no additional investments for the home-stays, this is a profitable supplementary income for the residents. A typical home-stay in Velas would just have extra beds for the guests. All other facilities are shared with the family this includes dining area, toilet and bath facilities and the common areas. In our survey we did not find a single air conditioner in any of the home-stays.

The residents have formed committees to manage common issues. Home-stay and tourism policies and managing garbage are jointly decided. The committee manages a website which advertises the home-stays and tourists can book over phone, eliminating any agents. To make the facilities customer friendly, the home-stay families are trained in basic conversational English, hospitality etiquettes and garbage management. A handy list of commonly used English terms is displayed in the house. The family stocks bottled water for sale and the empty bottles are separated in the trash. Plastic bags are not encouraged and Upadhaye said that the self-help groups will soon offer newspaper bags to the local shops. Every homestay has a register which helps maintain records of tourists. This system is meticulously maintained and has been appreciated by the police and Customs officials. Similarly, another register provides tourists' feedback to owners. This register is periodically reviewed for new ideas and suggestions. Such management has ensured that tourists get a uniform experience. As a result, positive testimonials are usually received from them. The beach is protected from overuse. Boating and parasailing is not allowed. In the daytime, tourists are offered nature trails with local experts. The trail follows forest walks and bird nests. This is a popular activity and is offered free. The village has formed teams of volunteers which periodically clean the beach. Junk trashed in nearby tourist beaches - Murud, Anjarle, Kelshi ends up in Velas beach and this is collected and segregated by the teams.

During this study, two local shopkeepers were interviewed in Velas. Remarkably, both were well aware of environmental issues. They had trash cans for plastic and segregated bottles, plastic and other things. The interview with Deepali Patil, the Sarpanch (village head), also yielded insights. She was well aware of the benefits of preserving the local biodiversity. She confirmed that the Turtle Festival was a success for villagers and provided additional income. She even commented that Velas might witness a return of villagers working in Mumbai and Pune, due to the Turtle Festival.

\section{Environmental impacts of Eco-tourism in Velas}

An analysis of environmental impacts at Murud is already done in an earlier section. For a comparison, these impacts were surveyed in Velas. A discussion follows:

a. Impacts $\mathrm{a}, \mathrm{b}$ and $\mathrm{c}$ were not noted in Velas. The reason for this is no additional building activity and far lower number of tourists visiting Velas. However, growth in mango farming has not been correlated to tourism.

b. Impact $d$, $e$ and $f$ have been somewhat noticeable. The increasing mango prices offer a lucrative business proposition to land owners. Similarly, increased energy and water consumption is more due to changing habits of residents and less due to demands of tourists.

c. Impact $\mathrm{f}$ - garbage has increased noticeably and is attributed to increased tourist visits. The tourists consume bottled water and packaged snack foods far more than local residents. This was confirmed by the two shopkeepers. There is no garbage collector visiting Velas. The waste is neither burned nor used for landfills and hence the huge collection is a major problem. From this month, one garbage dealer will visit Velas but he has agreed to collect only rubber (chappals and slippers brought in by the tide) and PET bottles. Despite efforts of the villagers to get scrap dealers, there seems to be no way out at the moment,

\section{Benefits of eco-tourism not noticed at Murud}

a. Tourists are more sensitive to local traditions and environment. The Sarpanch and Mohan Upadhye both said that tourists help in conservation efforts. Children are particularly more diligent in forest trails and have helped in bird nest spotting and animal sightings. Helping residents in their daily chores is an enjoyable and educating activity. In the feedback, some tourists noted that their children gained much from the visit. A significant portion of visitors wished to make another visit. This study proposes that such tourism can offer an educating experience for tourists and one that has the potential to increase their environmental sensitivity.

b. Encourages local produce, traditions and culture. In Velas, tourists do not demand tub baths and air conditioners. Based on the feedback records, most enjoy dining and sleeping on mud floors. They want to participate in traditional activities and buy locally made stuff. The locals realize the importance their produce, traditions and culture holds for the tourists. Its preservation holds an economic 
importance for them. In Velas, unnatural lighting and decoration is not required to attract attention. Tourists get to eat authentic Konkani cuisine that the family prepares. Traditional drinks like Kokam and Gingerlemon sarbats are sampled. All this has ensured that Velas preserves its character inspite of the tourists. This survey discovered the opposite condition in Murud. To please tourists, resorts are built in a citylike architecture. Amenities and services offered in Murud are no different from those in cities. Menus on offer are the ever popular Chinese, Moghlai and Punjabi. Local drinks are replaced by bottled beverages. Televisions in rooms engage tourists more than connecting with nature. Other than 'being' in Murud, tourists hardly have any reason to believe they are away at a Konkani village.

c. Environment does not pay for tourist growth. The turtle conservation program has an economic value for the villagers. Similarly, the sustainable lifestyle followed by the residents for centuries now has a reason to continue. Contrary to Murud, tourism motivates them to preserve the environment and continue traditions which have worked for centuries. This, the author believes, is the real success that ecotourism should be judged with.

\section{The way ahead for Eco-tourism}

Based on the detailed research conducted in 1997, Prakash Gole (1997) proposed a detailed framework for biodiversity conservation in the coastal region. The report recommended that besides the currently protected areas in Konkan, biosphere reserves (BR) and sites of Special Scientific Interest (SSI) be formed where tourism is not allowed. This author proposes extensions to Prakash Gole's eco-tourism recommendations, as discussed below.

a. No tourism permitted in any of the protected areas and proposed biosphere reserves. This should be a non-negotiable point.

b. In eco-sensitive areas suggested by the report, only tourism focused on conservation and based on 'Home-stays' be permitted. This restricts residents from making any constructions specifically for tourists - including rooms, toilet blocks, sit-outs and walkways. No trees are allowed to be removed for construction activities.

c. Preparation of a scientific management plan for private forests and promoting sustainable tourism in these areas as suggested by the WRCF report (Kulkarni \& Mehta, 2013). Restrictions on construction activities and clearing of trees must be enforced in these few remaining private forests. d. The much needed village-level biodiversity action plans (Deshmane, 2013) must be rolled out in all the districts. This aims to encourage decision making benefiting the village commons and is expected to support ecotourism.

e. A set of directive principles should be framed by the department of Tourism, Government of Maharashtra under which a village voluntary committee shall set the rules of Eco-tourism. The committee will, considering the local context and needs, prepare a voluntary code of conduct for the home-stay owners. The committee will decide the room pricing, joint promotion of all the home-stays, rules for conducting business and rules for managing garbage. This will ensure that local individuality is protected and local needs are addressed.

f. Eco-tourism is founded on collective agreement to a shared vision of managing the village 'commons' and hence based on restraint and individual sacrifice for the greater common good. The tourists are expected to comply with the rules. The rules and common goals of the village must be available for tourists for reading and agreeing with. Without communicating to them, they cannot be expected to behave in a desired manner.

g. Extending Prakash Gole's recommendation Eco-tourism should be promoted through correct scientific information. The more the dissemination, the better is the likelihood of achieving desired outcomes. Use of social media and the internet offers maximum reach at low costs. This needs to be employed effectively. Involvement of village members, school children and tourists together could be the key to successful voluntary compliance. The villagers must experience a sense of pride and the feeling of doing something worthwhile for the environment, posterity and their long term well being.

\section{Key Lessons for Murud}

The key principles of ecotourism are validated ecotourism seems to be working for Velas. Citizen of Murud can well adopt some of the tested methods of Velas, to suit the local conditions in here. Some of the key lessons suggested for Murud, by this study are :

(a) Tourism with restraints. A free market economy encourages consumption, as experienced in Murud today. This needs to be restrained by collective agreement. Setting common goals which are ecologically and economically sustainable and formulating rules and policies to reach them is the first step, one which Murud resort owners must take immediately. Since natural resources play an 
important role in their lives and livelihoods, the common goal must be conservation of nature. Collective decisions should include tourist management, resource usage and waste management.

(b) Growing with the right customers. Choosing the right customers, the author feels, is the key to achieving sustainability goals. Having set the common goals for the village, tourists seeking beach activities and indulging in alcohol induced recreation should not be encouraged. Replacing the current tourist offering with cultural and nature based educative activities can drive the change. On face value, this recommendation may seem risky - would tourists buy these services at all? Current customers may be lost but they will, over time be replaced by ones who are interested in what Murud offers. The switch will certainly not be quick and simple; however, it will be beneficial in reducing the impact on Murud's natural environment, the main source of tourist attraction. Similar recommendation is given by Purva (2011) and one study in India suggests that a pattern can be seen in eco-tourists (Siva \& Solomon, 2014).

(c) Harnessing the power of information to improve awareness. Disseminating information about the role of tourists in ecologically sensitive tourism. A common village website, booklets with resort owners and village signage have worked in Velas. Similarly, educating the resort owners is of paramount importance. NGOs can be helpful here, since advice emanating from village coworkers is often considered less worthy.

\section{In conclusion}

Many countries already have policies in existence for managing and promoting eco-tourism. New Zealand, notably, has a growing industry which supports eco-tourism and conserves natural resources of the small island country (Higham, Carr, \& Gale, 2001). Similarly Sri Lanka, our neighbor, has led the turtle conservation movement since 1988 and ecotourism has been funding it.

Growing tourism and the demand for 'secondhomes' has already put the fragile remains of biodiversity of Konkan under severe pressure. While everyone agrees that the environment has paid a huge price, no one quite knows when the government will pull up its act to address the challenge. Each one of us and the generations to come are and will be affected by the changing Konkan landscape and its dwindling biodiversity. We have already experienced the fury of the Tsunami in absence of mangrove covers. Many such calamities, consequences of human interventions, may yet be lurking below the surface. Eco-tourism has the potential to benefit residents, tourists and the environment, provided each stakeholder makes some sacrifices. This, according to this author, seems to be the pragmatic way ahead, instead of waiting for the government to extend a 'command and control' regime.

\section{Acknowledgement}

The author thanks the students of batch 13-14 for data collection at Murud. Amar Oke and Abhay Jail conducted detailed surveys at Velas, which is gratefully acknowledged.

\section{Bibliography}

Deshmane, A. (2013, January). Konkan to get village-level biodiversity action plans. Down to Earth.

Diamond, J. (2000). Collapse.

Gadgil, M. (2010). Ratnagiri and Sindhudurg districts: Summary report of the Maharashtra Government consultation. Pune: M.E.S. A.Garware College.

Ganu, W. (1958). Murud - Aitihasik ani Sanskritik. Murud: SAKGS.

Garg, A., Naswa, P., \& Shukla, P. (2013). Impact assesment and Management: A case study of Konkan Railway. New Delhi: UNEP.

Gole, P. (1997). Conservation of Biodiversity of the West Coast. Pune: The Ecological Society.

Gole, P. (1998). Katha Kokan Kinaryachi. Pune: Continental.

Hardin, G. (1968). Tragedy of the Commons. Science, 1243-1248.

Higham, J., Carr, A., \& Gale, S. (2001). Ecotourism in New Zealand: Profiling visitors to New Zealand ecotourism operations. Dunedin, New Zealand: University of Otago.

Katdare, V. (2012, January). An update on Olive Ridley turtles along the west coast of Maharashtra, India in 2011-12. Indian Ocean Turtle Newsletter.

Katdare, V., \& Mone, R. (2003). Turtle Conservation in Konkan, Maharashtra. Kachhapa, 11-15.

Kulkarni, J., \& Mehta, P. (2013). Status, Distribution and Dynamics of Private and Community Forests in Sahyadri-Konkan Corridor of Maharashtra Western Ghats. Pune: Wildlife Research and Conservation Society.

Pawar, A. (2013, March). Highlights of Budget Speech 2013. Retrieved from Maharashtra Government: https://www.maharashtra.gov.in/PDF/BudgetHigh lights_2013_English_Part_I.pdf

Purva, D. (2011, November). An Emerging Need for Visitor Management (The Indian Experience). Retrieved from ENVIS tourism: http://www.envisecotourism. 
nic.in / arcindexx.aspx?langid $=1 \&$ slid $=160 \& \mathrm{mid}=$ 2\&sublinkid $=33$

Shindikar, M. (2009). Coastal Areas - Problems and Conservation with a special reference to Mangroves in Maharashtra, Pune.

Siva, S., \& Solomon, L. J. (2014). Impact of EcoTourism on Environmental development: A Study with reference to Asian Research Journal of Business
Management.

Watve, A. (2013). Status review of Rocky plateaus in the northern Western Ghats and Konkan region of Maharashtra, India with recommendations for conservation and management. Journal of Threatened Taxa, 3935-3962.

Weaver, D. B. (2001). Ecotourism. Sydney: John Wiley \& Sons. 